Електронне наукове фахове видання "Ефективна економіка" включено до переліку наукових фахових видань України з питань економіки (Категорія «Б», Наказ Міністерства освіти і науки України від 11.07.2019 № 975) www. economy.nayka.com.ua | № 3, 2021 | 25.03.2021 p.

DOI: $\underline{10.32702 / 2307-2105-2021.3 .80}$

УДК. 330.522.4

K. Redko

$P h D$ in Economics, Senior Lecturer,

Faculty of Management and Marketing, International Economy Department, National Technical University of Ukraine "Igor Sikorsky Kyiv Polytechnic Institute"

ORCID ID: 0000-0003-2609-3471

O. Batyuk

student of the group UM-01, Faculty of Management and Marketing,

Department of Industrial Marketing, National Technical University of Ukraine "Igor Sikorsky

Kyiv Polytechnic Institute"

ORCID ID: 0000-0002-6424-9804

\title{
ALTERNATIVE ENERGY IN UKRAINE: BLESSING OR PUNISHMENT?
}

\author{
К. Ю. Редько, \\ к. е. н., старший викладач, Факультет менеджменту та маркетингу, Кафедра \\ міжнародної економіки, Національний технічний університет Украӥни «Київський \\ політехнічний інститут імені Ігоря Сікорського» \\ О. О. Батюк,
}

студентка групи УМ-01, Кафедра промислового маркетингу, Факультет менеджменту та маркетингу, Націона́льний технічний університе́т Украйни «Кйївський політехнічний інститу́m їмені І́горя Сіко́рського», м. Київ

\section{АЛЬТЕРНАТИВНА ЕНЕРГЕТИКА В УКРАЇНІ: БЛАГОСЛОВЕННЯ ЧИ КАРА?}

The article highlights the idea of using alternative energy sources and their growing popularity over the past 20 years. The definition of alternative energy is given. Environmental problems are gaining momentum, so alternative energy sources are becoming one of the most important mechanisms for resolving and reducing man's negative impact on the environment. The negative aspects of electricity production through coal combustion are presented. The level of use of "green" energy in different countries of the world and their plans for further developing this industry are illustrated. Data on the growing interest in renewable energy sources, the increasing level of investment are presented. Scientists warn that fossil resources will be enough for humanity for 50 years. EU countries plan to increase the share of renewable sources in the structure to $50 \%$ by 2030 when Ukraine sets the bar at only 13\%. The types of energy in Ukraine and their share as of 2020 are presented in a pie chart. The shares of alternative sources are 
given, and the volumes of "green" energy production capacities by Ukraine regions are compared. The key idea of the European energy market is highlighted - the best electricity that is not produced. The problem of price increase for the final consumer is considered. It was researched and found that foreign investors mostly invest in this industry; components are imported from abroad at reduced rates, due to which the state loses funds that could go to the budget. At the intersection of 2019 and 2020, a record electricity surplus was registered, which forced Ukrenergo to limit traditional generation production. Although in 2017, after the active introduction of alternative energy, prices for final consumers increased by $30 \%$, the cost of electricity in Ukraine remains the lowest in Europe. Conclusions are made on the state of the energy system of Ukraine, possible positive aspects of the use of renewable energy sources for the state. The energy potential of the "green" industry of Ukraine in comparison with some European countries is estimated. An assessment of the prospects of the "green" energy sector in the Ukrainian market has been made.

У статті висвітлена ідея використання альтернативних джерел енергї та ї̈ наростаюча популярність останніх 20 років. Наведено визначення альтернативної енергетики. Екологічні проблеми набирають надзвичайних обертів, тому використання альтернативних джерел енергії стає одним із найактуальніших механізмів врегулювання та зменшення негативного впливу людини на навколишнє середовище. Наведено негативні аспекти виробництва електроенергї через спалювання вугілля. Проілюстровано рівень використання “зеленоі" енергетики в різних краӥнах світу, їх плани щцодо подальшого розвитку иієё галузі. Наведено дані щодо зростаючого інтересу у відновлювальних джерелах енергії, зростаючий рівень інвестування. Вчені попереджають, щьо викопних ресурсів людству вистачить на 50 років. Краӥни СС до 2030 року планують підвищити частку відновлювальних джерел в структурі до 50\%, коли Україна ставить планку лише в 13\%. Зображено у вигляді кругової діаграми види енергї в України та їх частка станом на 2020 рік, наведено частки альтернативних джерел, порівняно об'єми потужностей виробництва "зеленої" енергії за областями України. Висвітлена ключова ідея енергетичного ринку Свропи - найкращу електроенергія та, яка не вироблена. Розглянуто проблему підвищення цін для кінщевого споживача. Досліджено та виявлено, щзо дана галузь здебільшого інвестується іноземними капіталовкладниками, комплектуючі ввозяться з-за кордону за зниженими тарифами, через що держава втрачає кошти, які могли б надійти до бюджету. На перетині 2019 та 2020 років було зареєстровано рекордний профіічит електроенергї, щя змусило “Укренерго” обмежити виробництво традищійної генерачії. Хоча у 2017 рочі після активного впровадження альтернативної енергії ціни для кінцевих споживачів зросли на 30\%, изіна на електроенергію в України й досі залишається найменшою в Свропі. Зроблено висновки щодо стану енергетичної системи Украӥни, можливих позитивних моментів використання відновлювальних джерел енергї для держави. Оцінено енергетичний потенціал “зеленоі" галузі Украӥни в порівнянні з деякими краӥнами Європи. Зроблена оиінка перспективності галузі “зеленої” енергетики на ринку України.

Keywords: alternative energy sources; fossil resources; ecology; investments.

Ключові слова: альтернативні джерела енергї; викопні ресурси; екологія; інвестищї. 
Formulation of the problem. For Ukraine at this stage, development is characterized by a significant need to import energy, lack of sufficient opportunities for alternative production some energy sources. The solution to these problems depends on efficiency of public administration in the field of development alternative energy sources. Unfortunately, modern energy consumption is largely based on use non-renewable reserves of fossil fuels coal, oil and gas. As a result, it creates an energy problem: fast depletion of non-renewable fuels at an increasing rate its consumption.

Analysis of recent research and publications. Scientists such as G. Brandl, I. Haidutsky, S. Katyshev, D. Taylor, E. Yambor, B. Chobanova, and others. devoted their publications to the analysis of the current state and problematic aspects of developing alternative energy in Ukraine to determine the effectiveness of this industry's state regulation mechanisms. [1-3].

The purpose of the article. Investigate the state of use of alternative energy, compare the level of development and share of renewable sources in the most developed countries and Ukraine, draw conclusions about the level of "green" energy in Ukraine, prospects for the development of this industry and determine the appropriateness of alternative energy at this stage.

Presenting the main material. Over the last 20 years, the idea of using alternative energy sources has attracted more and more attention [4]. Humankind directly or indirectly affects the environment through its activities. The level of danger of a global catastrophe from climate change, water pollution, destruction of entire ecosystems, the formation of ozone holes, etc., increases significantly every year, threatening the complete or partial collapse of the tired way of life. To reduce the threat level, states are taking specific steps towards sustainable coexistence with nature and Earth. One of these is the transition to the use of alternative energy sources. Despite their most significant advantage for humanity - infinite supply, they also do not harm the environment.

Despite their exhaustion, conventional energy sources are also expensive and dangerous. The new NPP unit's commissioning costs $€ 7$ million, and the closure of production costs $€ 1.3$ million. Large sums are also spent on maintaining the safety of the operation of such a plant.

Coal energy production is considered to be more emergency and harmful. By penetrating deep into the skin, coal dust is detrimental to human health. It is also necessary to mention the accident rate of coal mines: every year, at least 100 miners died while working in the mine. Also, the production of electricity through coal combustion is unprofitable - only $33 \%$ of energy is converted into electricity after combustion. Gas generating stations have a slightly but not too high rate.

"There is no alternative to renewable energy sources. It is necessary to strengthen the quality of Ukraine's strategic policy to increase the share of green energy in the economy, based on the fact that it affects all spheres of life. These goals can be achieved only based on dialogue when public and private partnerships are combined, all those working in this sector, including international experience, advanced technologies "- said the President of the Ukrainian Union of Industrialists and Entrepreneurs, Anatoliy Kinakh, on the table in Ukrinform on the topic: "Alternative energy in Ukraine: opportunities for investors and producers" [5]. Thus, there is a need to study international practices.

Most developed countries have big goals. Germany, for example, promises to switch entirely to renewable energy by 2050. Norway, Iceland, and Paraguay meet their domestic needs through alternative energy while remaining among the largest oil and gas exporters. In one day in 2015, Denmark provided 140\% of its electricity consumption to wind farms, the remainder of which is sold to Germany, Sweden, and Norway. Costa Rica has experienced a complete transition to alternative energy for 75 days due to prolonged downpours. Lower Austria was able to abandon coal-fired power plants, saying that hydropower plants' operation on the Danube was enough to provide the country with energy. \$ 97 billion invested in renewable energy in the Middle East and North Africa [6]. Investment in renewable energy continues to grow compared to fossil energy sources (Fig. 1). 


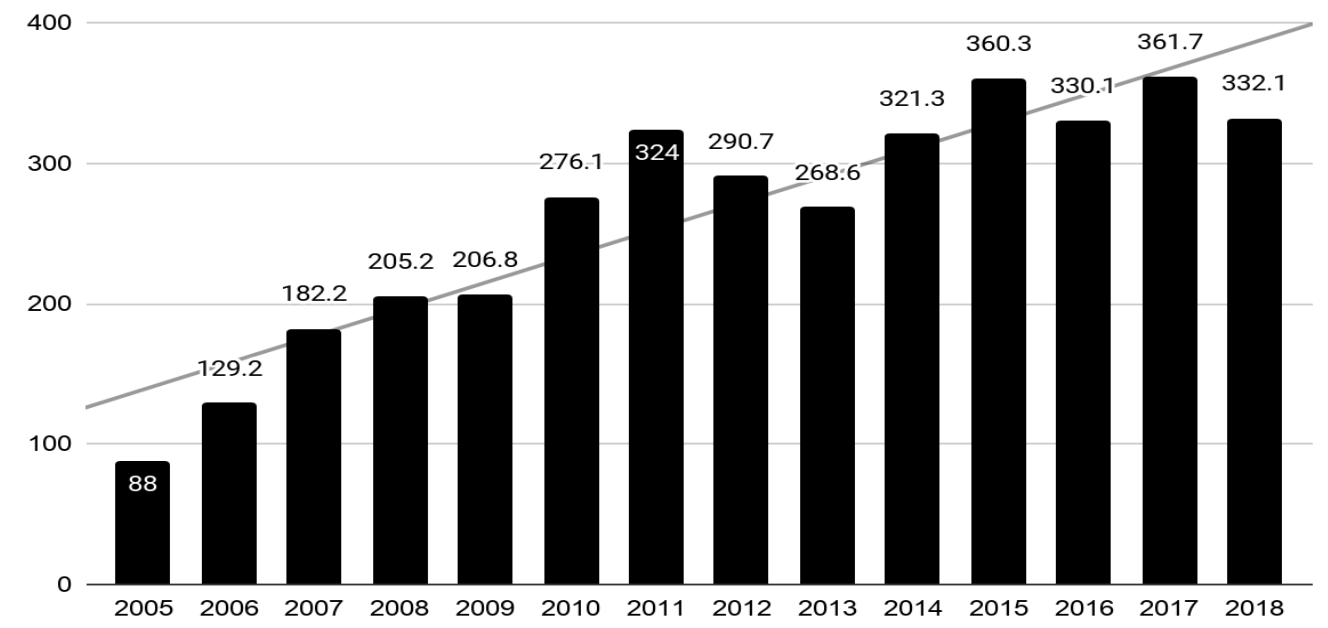

Fig. 1. Global investment in RES in 2005-2018 [7]

In 2015, the industry received twice as much global funding; despite falling gas, coal, and oil prices, these industries have declined significantly while renewable energy is thriving [8]. The success of renewable energy in 2015 is explained by the initiatives of the G20 countries to ensure comfortable conditions for economic competition, environmental protection, access to modern energy sources of all nations, especially those that are developing and have the most significant demand for this type of energy. The Paris Climate Agreement has established the priority of renewable energy for the world.

According to scientists' latest estimates, fossil resources - oil and gas - will be enough for humanity for 50 years. That is why many countries around the world are introducing the use of alternative energy sources. EU countries plan to increase the share of alternative sources in the structure by 2030 to 50\% (Fig. 2). In Ukraine, more modest plans - by 2025 , the percentage of renewable sources in electricity generation should be $13 \%$.

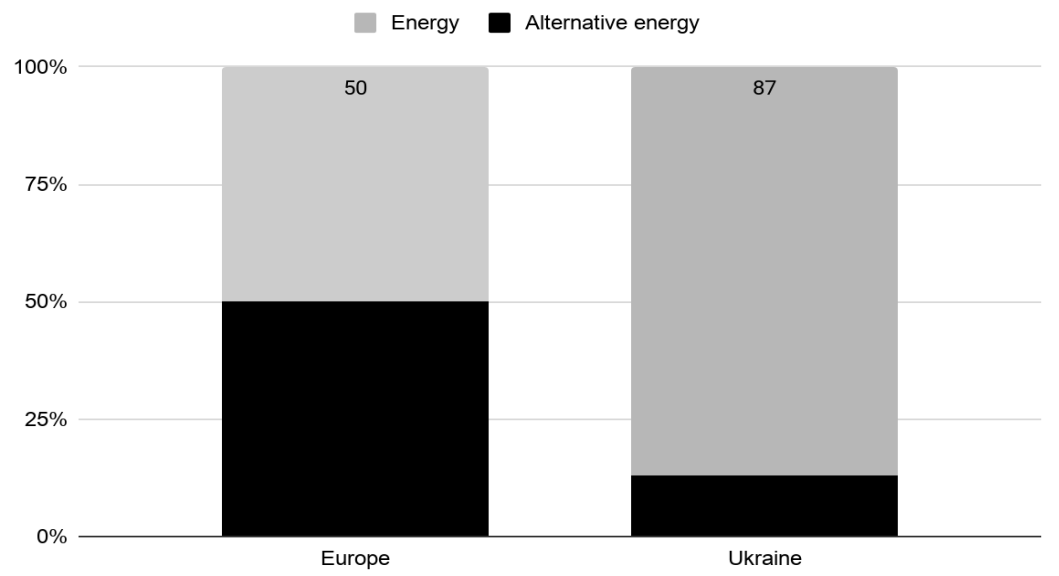

Fig. 2. The share of alternative energy sources in Ukraine and Europe, plans for 2030 (Table 1).

By 2035, Ukraine plans to increase the use of alternative energy sources and use less exhaustive sources 
Table 1. Structure of ZPPE of Ukraine, million tons [9]

\begin{tabular}{|l|c|c|c|c|c|c|}
\hline \multicolumn{1}{|c|}{$\begin{array}{c}\text { Name of primary } \\
\text { energy supply sources }\end{array}$} & 2010 & 2015 & 2020 & $\begin{array}{c}2025 \\
\text { (prediction) }\end{array}$ & $\begin{array}{c}2030 \\
\text { (prediction) }\end{array}$ & $\begin{array}{c}2035 \\
\text { (prediction) }\end{array}$ \\
\hline Coal & 38,3 & 27,3 & 18 & 14 & 13 & 12 \\
\hline Natural gas & 55,2 & 26,1 & 24,3 & 27 & 28 & 29 \\
\hline Petroleum products & 13,2 & 10,5 & 9,5 & 8 & 7,5 & 7 \\
\hline Atomic energy & 23,4 & 23,0 & 24 & 28 & 24 & 27 \\
\hline $\begin{array}{l}\text { Biomass, biofuels, } \\
\text { and waste }\end{array}$ & 1,5 & 2,1 & 4 & 6 & 8 & 11 \\
\hline Solar and wind energy & 0,0 & 0,1 & 1 & 2 & 5 & 10 \\
\hline HPP & 1,1 & 0,5 & 1 & 1 & 1 & 1 \\
\hline Geothermal energy & - & 0,5 & 0,5 & 1 & 1,5 & 2 \\
\hline Total & 132,3 & 90,1 & 82,3 & 87 & 91 & 96 \\
\hline
\end{tabular}

As of 2020, 7.3\% of Ukraine's electricity is produced using alternative sources (Fig. 3).

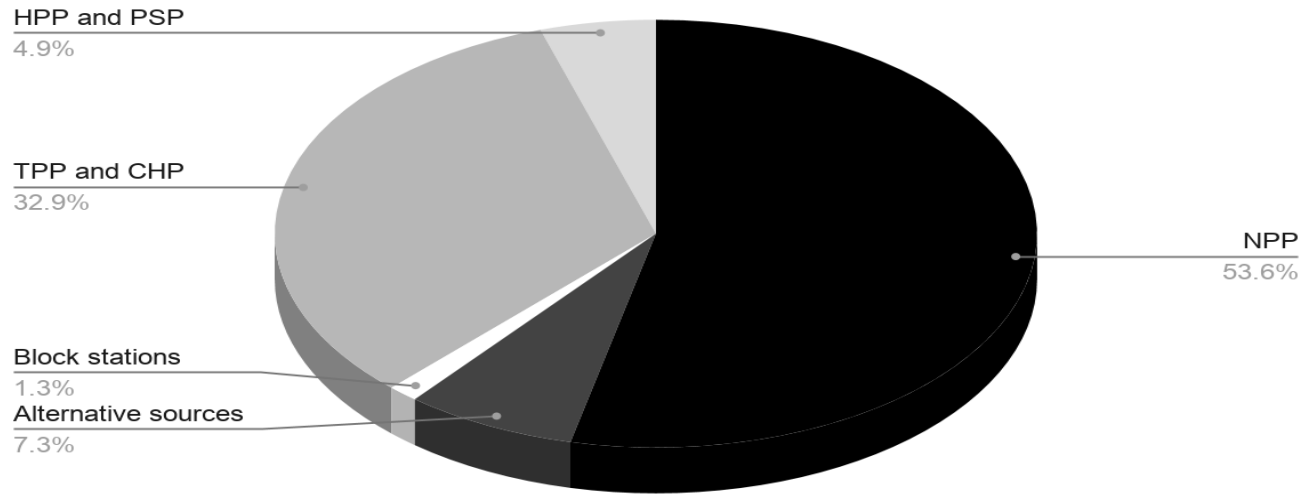

Fig. 3. Types of energy in Ukraine as of 2020 and their share

The undisputed leader among other alternative sources in Ukraine is solar energy. If at the end of 2019 the total capacity of RES is $3634.4 \mathrm{MW}$, then $72.65 \%$ - SES, which is $2640.4 \mathrm{MW}$. Wind turbines occupy second place with a significant gap - 21.37\% (776.6 MW), followed by biomass and biogas - 3.24\% (117.7 MW). The least popular are small hydropower plants; their share is $2.75 \%$ (99.8 MW) (Fig. 4) [10].

The Kherson region put an enormous amount of capacity - 543.6 MW, then Zaporizhia - 524.5 MW. It is followed (excluding the occupied Autonomous Republic of Crimea) by the Mykolayiv region with 419.8 MW, then Dnipropetrovsk - 389 MW. It should be noted that the Dnipropetrovsk region prefers solar energy and is among the top three in the number of solar installations. Odesa region uses 309.8 MW of renewable energy, Vinnytsia - 242.2 MW. Lviv and Khmelnytsky regions occupy the last positions with 213.3 MW and 201.9 MW, respectively [10]. 


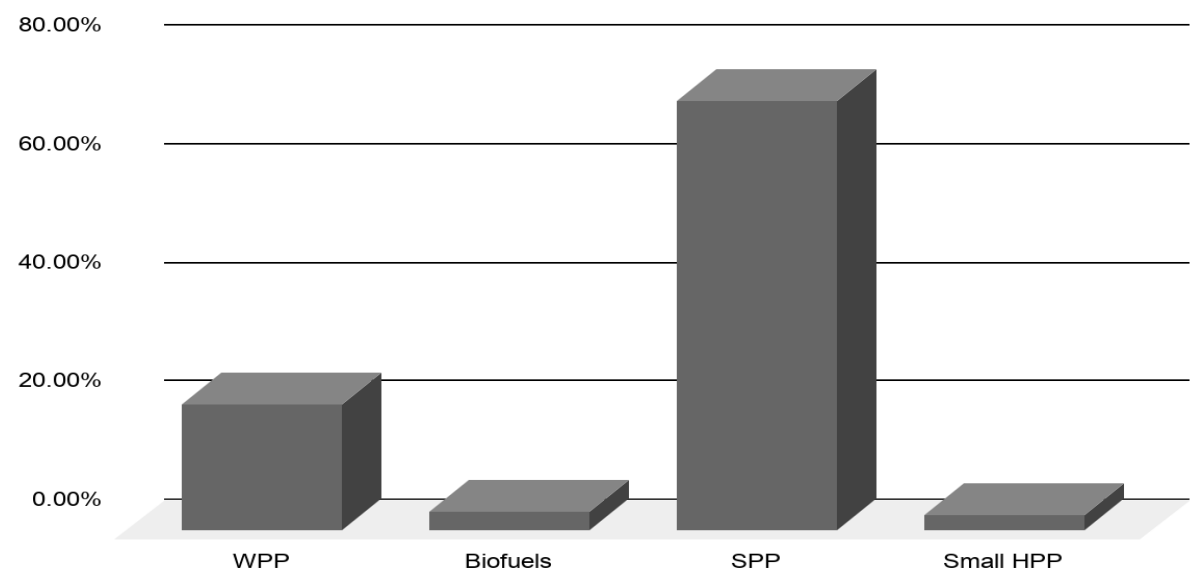

Fig. 4. Alternative energy sources in Ukraine and their share

The price a person has to pay for the final consumer of electricity is of great importance. Not everything is so positive here: raising household tariffs has been discussed for a long time. And from January 2020, industrial enterprises are already forced to pay 20-25\% more for electricity because the regulator NEC Ukrenergo does not have enough money to pay for the "green" generation.

What does Ukraine pay for? First, lending to green projects comes from European or Chinese investments, and therefore these investors are interested in making a profit. They are also interested in supporting the production of solar and wind power components in their own countries, which are also given loans.

Second, equipment and all components for all industrial wind farms and solar stations - thousands of hectares of solar panels and tons of wind turbines and equipment - are imported into Ukraine at preferential customs rates from China, Germany, Sweden, Spain, and more. Because of this, in 2019 alone, Ukraine's economy lost 9 billion hryvnias.

Recently, it has become clear that it is impossible to make a sufficient profit from "green" investments in Ukraine. This refers to the state level.

RES stations are usually built-in remote and sparsely populated areas. Therefore, communities invest heavily in improving communications with these facilities - building roads, hospitals, schools. But as a result, these facilities serve from 5 to 30 people, up to 50 more people can do the cleaning works for the station. Also, the issue of utilization of expired technologies is not raised in our country, which threatens to pollute the environment with artificial waste.

In Ukraine, in December 2019 and January 2020, the surplus of electricity in the system exceeded 3 GW the largest figure in the state's history. This forced Ukrenergo to limit all traditional generation of energy production. As this was not enough because too much energy was produced, restrictions were placed on wind farms and solar stations' operations. Although the Ukrainian economy did not need this unproduced electricity, producers of "green" electricity will still receive compensation from the state for unproduced energy.

In Europe, the central position is that "the best energy is the one that is not produced": if no one needs your energy, you should not produce it. The greatest attention is paid to energy saving in all industries; energy tariffs were reduced, and its production benefits were almost abolished. 


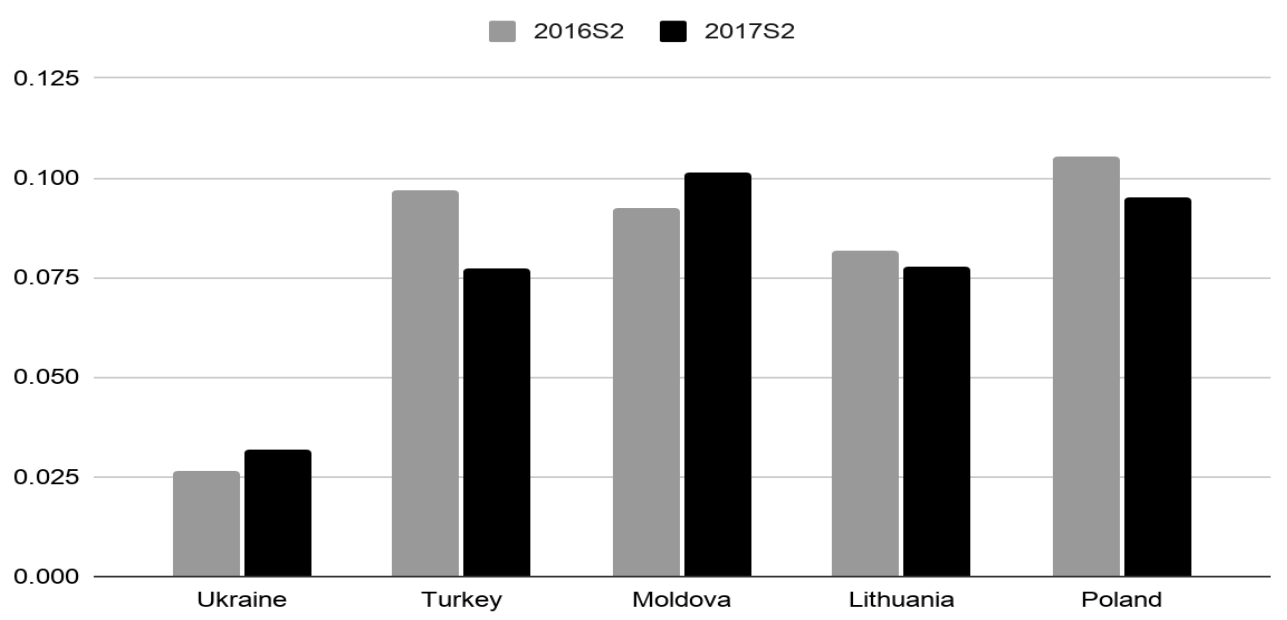

Fig. 5. Change in electricity prices for household consumers in the second half of 2017 compared to the second half of 2016(11)

Table 2. "Consumer price indices for goods and services" [12]

\begin{tabular}{|c|c|}
\hline Year & "Housing, water, electricity, gas and other fuels" \\
\hline 2010 January & 88,2 \\
\hline 2020 January & 549,2 \\
\hline
\end{tabular}

At the "peak" of the introduction of green energy in 2017 in Ukraine, the final consumer's electricity prices increased by more than $30 \%$ - the highest figure in Europe.

Although we see that the electricity index in Ukraine has grown over the last ten years, electricity prices remain the lowest in Europe (Fig. 6).

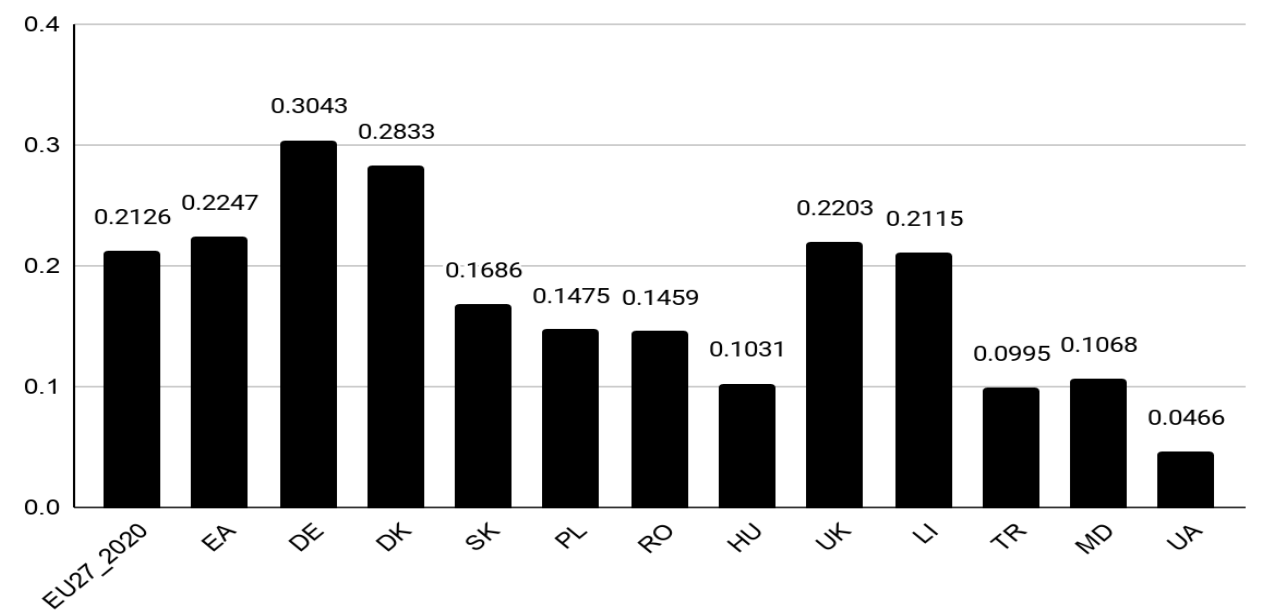

Fig. 6. Electricity prices (including taxes) for household consumers, first half 2020 [13]

In Figure 6, we can see the state of electricity prices in the first half of 2020. At 0.3043 in Germany, the price for electricity in Ukraine was 0.0466 - the lowest in Europe. In neighboring Moldova - 0.1068, Lithuania 0.2115, Poland - 01475, in general in Europe - 0.2126. 
Ukraine has great potential for the development of alternative energy sources. Ukraine is the largest country in Europe with a great variety of landscapes and opportunities for the integration of "green" energy into the functioning of the state.

The Ukrainian Black Sea coast, for example, is promising in the use of solar, wind, geothermal, and biomass energy resources. In coastal regions, the average annual wind speed exceeds $5 \mathrm{~m} / \mathrm{s}$, making these regions the most efficient in terms of wind energy use. Almost the entire area of the Sea of Azov can be used for the construction of wind farms on offshore platforms. The potential of solar energy in the Black Sea regions is about $1400 \mathrm{kWh} / \mathrm{m} 2$, which is on par with the countries that actively use solar energy (USA, Germany, Sweden, etc.) and save about 2.5 million tons of conventional fuel annually. It should be noted that the average annual potential of solar energy in Ukraine $(1235 \mathrm{kWh} / \mathrm{m})$ is relatively high and much higher than, for example, in Germany - 1000 $\mathrm{kWh} / \mathrm{m}$, Poland $-1080 \mathrm{kWh} / \mathrm{m}$. According to various estimates, potential geothermal energy resources in Ukraine will be able to operate geothermal power plants (GTSP) with a total capacity of up to 200-250 million kW (with drilling depths up to $7 \mathrm{~km}$ and periods of 50 years) and geothermal heat supply systems with a total capacity of up to $1.2-1.5$ billion $\mathrm{kW}$ (at depths of drilling wells up to $4 \mathrm{~km}$ and periods of 50 years). The Black Sea region has sufficient resources for the use of geothermal energy. Sufficiently powerful geothermal plants can provide energy and heat to Odesa, Kherson, Mykolaiv, Donetsk regions, and the Autonomous Republic of Crimea [15].

Conclusion. The rapid rise in energy prices, the presence of disruptions in their supply, dictated by political problems, demonstrated the weakness of the modern energy system of Ukraine, which is the basis of the socioeconomic development of the state. At the same time, alternative energy sources can compensate for the shortcomings of the existing energy system, as the country's energy reserves of solar, water, wind, and biological raw materials are virtually inexhaustible and will contribute to economic growth by reducing energy costs in all sectors. In addition, it should lead to a reduction in carbon dioxide emissions, as alternative energy sources significantly reduce their emissions, help solve environmental problems and improve the ecological situation in the country. [14] In Ukraine, there is a significant potential for the main types of renewable energy sources. Still, currently, they represent a relatively small share in the overall energy balance of the state. The lack of a system of preventive measures and disposal of artificial waste will negatively impact the country's economy and ecology if the implementation, maintenance, and decommissioning of renewable energy production plants are not developed. Currently, the state does not have positive changes due to "green" energy. Still, with the right approach and adjustment of activities on renewable energy sources, this industry will have very optimistic estimates, which may attract additional investment in the budget of Ukraine.

\section{References.}

1. State Agency for Energy Efficiency and Energy Saving of Ukraine (2021), "Potential of renewable energy in Ukraine", available at: http://www.saee.gov.ua/uk/activity/vidnovlyuvana-enerhetyka/potentsial (Accessed 1 October 2020).

2. State Agency for Energy Efficiency and Energy Saving of Ukraine (2021), "The current state of renewable energy in Ukraine", available at: http://www.saee.gov.ua/uk/activity/vidnovlyuvanaenerhetyka/suchasny-stan (Accessed 3 October 2020).

3. State Agency for Energy Efficiency and Energy Saving of Ukraine (2021), "In-depth policy review and programs of UKRAINE in the field energy efficiency", available at: https://saee.gov.ua/documents/Ukraine_EE_2013_RUS.pdf (Accessed 7 October 2020).

4. The Verkhovna Rada of Ukraine (2003), The Law of Ukraine "About alternative energy sources", available at: https://zakon.rada.gov.ua/laws/show/555-15\#Text (Accessed 13 October 2020).

5. Ukrainian multimedia platform for broadcasting (2021), "Alternative energy in Ukraine: opportunities for investors and producers", available at: https://www.ukrinform.ua/rubric-presshall/3073727alternativna-energetika-v-ukraini-mozlivosti-dla-investoriv-ta-virobnikiv.html (Accessed 17 October 2020).

6. Yakovlyeva, N. (2020), "Middle East and North Africa invest \$ 97 billion in renewable energy", available at: https://ecotown.com.ua/news/Kraini-Blizkogo-Skhodu-i-Pivnichnoi-Afriki-investuyut-uvidnovlyuvani-dzherela-energii-97-mlrd/ (Accessed 2 November 2020).

7. Bloomberg New Energy Finance (2021), "Energy Transition Investment Trends", available at: https://assets.bbhub.io/professional/ sites/24/Energy-Transition-Investment-Trends_Free-Summary_Jan2021.pdf (Accessed 19 January 2021).

8. Randall, T. (2016), "Wind and Solar Are Crushing Fossil Fuels", available at: https://www.bloomberg.com/news/articles/2016-04-06/wind-and-solar-are-crushing-fossil-fuels (Accessed 19 January 2021). 
9. Annex 2 to the Energy Strategy Of Ukraine for the period up to 2035 (2020), "Safety, energy efficiency, competitiveness", available https://mepr.gov.ua/files/images/news_2020/21012020/\%D0\%95\%D0\%BD\%D0\%B5\%D1\%80\%D0\%B3\%D0\%B5 $\% \mathrm{D} 1 \% 82 \% \mathrm{D} 0 \% \mathrm{~B} 8 \% \mathrm{D} 1 \% 87 \% \mathrm{D} 0 \% \mathrm{BD} \% \mathrm{D} 0 \% \mathrm{~B} 0 \% 20 \% \mathrm{D} 1 \% 81 \% \mathrm{D} 1 \% 82 \% \mathrm{D} 1 \% 80 \% \mathrm{D} 0 \% \mathrm{~B} 0 \% \mathrm{D} 1 \% 82 \% \mathrm{D} 0 \% \mathrm{~B} 5 \%$ D0\%B3\%D1\%96\%D1\%8F\%20\%D0\%A3\%D0\%BA\%D1\%80\%D0\%B0\%D1\%97\%D0\%BD\%D0\%B8\%20\%D0\% BD\%D0\%B0\%20\%D0\%BF\%D0\%B5\%D1\%80\%D1\%96\%D0\%BE\%D0\%B4\%20\%D0\%B4\%D0\%BE\%202035\%2 0\%D1\%80\%D0\%BE\%D0\%BA\%D1\%83\%20\%D0\%94\%D0\%BE\%D0\%B4\%D0\%B0\%D1\%82\%D0\%BE\%D0\%B A\%202.pdf (Accessed 19 January 2021).

10. Eurostat (2020), "Electricity prices for household consumers - bi-annual data (from 2007 onwards)", available at: https://appsso.eurostat.ec.europa.eu/nui/show.do?dataset=nrg_pc_204\&lang=en (Accessed 1 February 2021).

11. State Statistics Service of Ukraine (2020), "Consumer price indices for goods and services". Derzhkomstat, Kyiv, Ukraine (Accessed 10 February 2021).

12. Eurostat (2020), "Electricity prices (including taxes) for household consumers, first half 2020", available at: https://ec.europa.eu/eurostat/statistics-explained/index.php/Electricity_price_statistics (Accessed 11 February 2021).

13. Voloshyn, O. L. (2015), "Development of alternative energy in Ukraine: current state and effectiveness of state regulation mechanisms", Aktual'ni problemy derzhavnoho upravlinnia, vol. 1(47), pp. 176181.

14. The National Institute for Strategic Studies (2010), "Alternative energy sources in the Ukrainian Black Sea coast", available at: https://niss.gov.ua/doslidzhennya/nacionalna-bezpeka/alternativni-dzherelaenergoresursiv-v-ukrainskomu-prichornomori (Accessed 15 February 2021). 